\title{
"Environmentalism of the poor": the Tipaimukh Dam, ecological disasters and environmental resistance beyond borders
}

\author{
Md Saidul Islam and Md Nazrul Islam
}

*Correspondence:
msaidul@ntu.edu.sg
Division of Sociology,
School of Humanities
and Social Sciences, Nanyang
Technological University, HSS
05-44, 14 Nanyang Drive,
Singapore 637332, Singapore

Springer

\begin{abstract}
The Indian government recently resumed the construction of the Tipaimukh Dam on the Barak River just $1 \mathrm{~km}$ north of Bangladesh's north-eastern border. The construction work was stalled in March 2007 in the wake of massive protests from within and outside India. Experts have argued that the Dam, when completed, would cause colossal disasters to Bangladesh and India, with the former being vastly affected: the Dam would virtually dry up the Surma and Kushiara, two important rivers for Bangladesh. Therefore, this controversial Dam project has generated immense public discontents leading to wider mass-movements in Bangladesh, India, and around the world. The movement has taken various forms, ranging from simple protests to a submission of a petition to the United Nations. Drawing on the "environmentalism of the poor" as a conceptual metaphor, the article examines this global movement to show how environmental resistance against the Tipaimukh Dam has transcended national borders and taken on a transnational form by examining such questions as: who is protesting, why, in what ways, and with what effects. In order to elucidate the impending social and ecological impacts, which would potentially disrupt communities in South Asia, the paper offers some pragmatic policy recommendations that also seek to augment social mobility in the region.
\end{abstract}

Keywords: Environmentalism, Tipaimukh Dam, Ecological disaster, Environmental resistance, Social movement, Bangladesh, Economic and social impacts

\section{Background}

Lower-riparian Bangladesh and upper-riparian India share more than 50 international rivers (Adel 2012: 528; Riaz 2011: 106; Islam 1992: 204; Ahmed 2012: 51; Afroz and Rahman 2013: 100). ${ }^{1}$ Needless to say, historically these rivers are very important, playing a vital part in many ways in people's lives, such as, in agriculture and fisheries, vegetation and greenery, urban and rural water supplies, and navigation and communication. However, India has set up constructions for water diversion in more than 50 percent of these rivers. The largest one is upon the Ganges River commonly known as the Farakka Barrage, which puts Bangladesh's ecosystem at stake. In some border rivers, India has set up

\footnotetext{
${ }^{1}$ Experts have tended to show varied number of international rivers shared by Bangladesh and India: Islam (1992) says fifty-seven rivers are common to India and Bangladesh, while Riaz (2011), Ahmed (2012), and Afroz and Rahman (2013) write the number is fifty-four, and Adel (2012) says it is more than 50. Thus, we prefer to take the phrase 'more than 50.'
}

(c) 2016 Islam and Islam. This article is distributed under the terms of the Creative Commons Attribution 4.0 International License (http://creativecommons.org/licenses/by/4.0/), which permits unrestricted use, distribution, and reproduction in any medium, provided you give appropriate credit to the original author(s) and the source, provide a link to the Creative Commons license, and indicate if changes were made. 
groins on her side of the river banks. Furthermore, Bangladesh River water is pumped stealthily from border-rivers by entities on the Indian side (Adel 2012). India's decisions to build diversion constructions in international rivers and the arbitrary control of transnational rivers' waters leading Bangladesh to suffer economically, socially and ecologically have triggered unending debates and resistances over the years. ${ }^{2}$ Nevertheless, the debate with Farakka Barrage and the Gajoldoba Barrage ${ }^{3}$ on the Teesta River is conceived to be overshadowed by India's recent decision to build another Dam, now at the Tipaimukh on the river Barak. India's unilateral plan has prompted a wide range of debate and discussion on its merit in both India and Bangladesh (Mirza 2009). The debates have gradually transcended the realm of government officials and academics, and transformed into various modes of protests and resistance in India, Bangladesh, and beyond.

Officially called the Tipaimukh Multipurpose Hydroelectric Dam Project (henceforth the Tipaimukh Dam) on the Barak River ${ }^{4}$ is just $1 \mathrm{~km}$ north of Zakiganj in Sylhet, Bangladesh. Theis Dam is spotted 500 meters downstream from the flowing rivers of Barak and Tuivai and sited in the south-western corner of Manipur state of India. Its reservoir will have a water storage capacity of 15,900 million cubic meters with a maximum depth of 1725.5 meters (Islam 2013: 156). Commissioned by India in mid 2000s, the Dam site lies in contiguity with two other states-Assam and Mizoram, that implies the involvement of three states of Northeast India in the project. The Barak River which flows downstream to join the Surma and Kushiara river systems in Bangladesh is considered to be the lifeline of the Sylhet region in Bangladesh. The Dam is estimated to generate $1500 \mathrm{MW}$ of hydroelectric power, though the original consideration was to contain flood-water in the Cachar plains of the Indian state of Assam (D'Costa 2012: 153; Ahmed 2012: 52). However, experts are concerned and have voiced apprehensions that the proposed Dam would cause colossal damage to Bangladesh's economy, society and environment, practically contributing to drying up two important rivers-the Surma (length: $350 \mathrm{~km}$ ) and the Kushiara (length: $110 \mathrm{~km}$ ) - which provide water for most of the northeastern region of Bangladesh (Rahman 2009; Mirza 2009; Khan 2009; Mastoor 2011; Islam 2013). It will also affect the virgin haor ecosystem of Bangladesh (Adel 2012).

Over the last few decades, Indo-Bangladesh relations have not been strained more by any issue other than that of water. India continues to unilaterally control and manage most of the international rivers that Bangladesh shares with her. Impacted by climate change, India has planned to divert waters, from the northeast of the country to its drought-prone west and south, notably some fifty-four common rivers which flow from

\footnotetext{
${ }^{2}$ India's withdrawals of Ganges waters at Farakka point and 90 other points within its territory alone has pushed Bangladesh into a state of extreme vulnerability. Experts have said that the reduced flow of the Ganges in Bangladesh has caused scarcity of fresh water, species endangerment and extinction, obstruction to livestock raising, loss of livelihoods, people's displacement, changes in crop production, reduction in navigable routes, extreme weather, increased flood occurrences, scarcity of potable water, groundwater contamination, reduction in costal sediment deposition, deterioration of the Ganges water quality and inland intrusion of saline water front (see Adel 2012).

3 As a part of irrigation project, India, in 1985, built Gajoldoba Barrage on Teesta River (at Gajoldoba, Jalpaiguri, West Bengal) that is commonly shared by both India and Bangladesh that seriously and adversely affects the latter particularly in agriculture and livelihoods. In response, Bangladesh, in late 1990s, built Teesta Barrage on Teesta River at Duani, Hatibandha of Lalmonirhat district. Due to upstream India's arbitrary roles in water sharing, Bangladesh still suffers from withdrawal of waters by India through Gajoldoba Barrage.

4 Barak River has originated from the southern hills of Nagaland and passed through Manipur and Cachar in Assam, and entered Bangladesh joining the basin of Surma and Kushiara flown all the way to Meghna and Padma (Sinha 1995).
} 
upstream India to downstream Bangladesh (Kazmi 2009). Over the last several years, there have been intense debates between the academic circles, civil society, environmental groups, human rights organizations and the media in Bangladesh over the implications of the Tipaimukh Dam upon the dividend of water coming from upper-riparian India. This debate continued to get new impetus since the protest movement expanded to the transnational space (Rahman 2009; Islam 2013).

This study was conducted employing a triangulation of methods: a global ethnography based on a robust Internet search focusing on social media; correspondence with two dozen protesters in Canada, the United States, the United Kingdom, and Bangladesh; and qualitative interviews with ten policy analysts comprising UN officials, academics, and government officers from India and Bangladesh. We also use "intellectual activism" as a novel methodological tool for our analysis. Using "environmentalism of the poor" as a conceptual metaphor, we examine: (a) how environmental resistance against the Tipaimukh Dam has transcended national borders and taken on a global and transnational form; (b) who is protesting, why, in what ways, and with what effects. The paper provides an important insight of an Asian environmentalism which has originated in Asia but formed a global alliance, and offers pragmatic policy recommendations aiming to spur social change and development.

Following this brief introduction, the paper in the second section delineates "environmentalism of the poor" as a conceptual metaphor. Drawing on this conceptual framework, the paper in the third section examines the potential environmental and social impacts of the Tipaimukh Dam that have largely generated this movement. The fourth section sketches out the diverse methods of environmental protests and alliances surrounding the Tipaimukh Dam. The paper concludes in the last section by raising some crucial issues which have broader policy implications seeking to encourage social change not only for the South Asian region but also for other parts of the world.

\section{Environmentalism of the poor}

Social or environmental movements consist of a large number of people who organize themselves to promote or resist social change. Social movements can be either proactive- to promote social change- or reactive- to resist any social change. Sidney Tarrow (1994: 3-4) defines social movements as "collective challenges by people with common purposes and solidarity in sustained interaction with elites, opponents and authorities." His definition outlines four basic properties of social movements: collective challenge, common purpose, solidarity, and sustaining collective action. Social or environmental movements arise from widespread, deeply felt discontent, from the conviction that some condition of society is no longer tolerable (Henslin 2011). Under these conditions, "environmentalism of the poor" proliferates.

Combining both environmental philosophy and activism, much has been written on various contours of environmentalism in the Global North ranging from the nature conservation movement to deep ecology to the new environmental paradigm (Islam 2013). While the previous trends continue to dominate the whole corpus of environmentalism

5 "Intellectual activism" is mainly a concept developed by sociologist Patricia Hill Collins (2013); see her book On Intellectual Activism (Temple University Press, Philadelphia). Intellectual activism requires sharp thinking and research, honest and dispassionate analysis, and common sense grounded in experience and observation on a subject. 
literature, the new trend seeks to delve into the environmentalism of the Global South. This new trend, still in the making, has been drafted with various titles. It has also been appropriately called livelihood ecology (Gari 2000), or liberation ecology (Peet and Watts 1996). While other scholars of global environmentalism such as Martinez-Alier (2002, 2014), Nixon (2011), Guha and Martinez-Alier (1997), Iain Davey (2009), and Anguelovski and Martinez-Alier (2014) have indiscriminately used the term "environmentalism of the poor" to refer to as the environmentalism of the Global South.

Environmental justice as an organized movement has been almost confined to its "country of origin"-the United States, while popular environmentalism or livelihood ecology or the "environmentalism of the poor" are names given to the myriad of movements in the Global South that struggle against environmental impacts that threaten poor people who are, in many countries, a majority of the population (Martinez-Alier 2002). Environmentalism of the South is thus appropriately given the title of the "environmentalism of the poor" since the poor people of the Global South have, by and large, been victims of the growth-centric development approach and the environmental footprints, and it is these poor people who have initiated and organized environmental movements in the South (Guha and Martinez-Alier 1997). This movement, to quote McMichael (2008: 245), "takes two forms: active resistance, which seeks to curb invasion of habitats by states and markets; and adaptation, which exemplifies the centuriesold practice of renewing habitats in the face of environmental deterioration. In the alter practice lie some answers to current problems."

While social construction of a boundary between Northern and Southern environmentalism often seems arbitrary, this distinction is periodically significant as the vibrant environmental movements in the Global South have been strikingly less represented in the discourse of environmentalism Islam (2012, 2013). In this paper, we will elucidate the environmental resistance against the Tipaimukh Dam in India as an example of the "environmentalism of the poor" focusing on the potential social and ecological costs of the Dam, dynamic and transnational nature of the resistance movement, and practical policy implications of this social and environmental activism for the geo-politics and social change of the region.

\section{Social and environmental impacts of the Tipaimukh Dam}

The environmentalists have posited that the Tipaimukh Dam would cause severe environmental and social disasters to both Bangladesh and India. Once completed, their primary concern centres around Bangladesh being deprived of its share of the international river that supplies waters to hundreds of water bodies in the region. They fear that the Dam would ultimately dry up the Meghna River in the greater Sylhet region and nearby districts, and the Surma and the Kushiara rivers in winter season which provide water for most of the north-eastern regions of the country. The Dam would severely affect agriculture and fisheries, vegetation and greenery including local flora and fauna, and generate a massive displacement of people and livestock in Bangladesh. The effects of the Dam are not only confined to Bangladesh as it also of serious consequences to the people of the Indian states of Manipur and Nagaland as the Barak-Surma-Kushiara is an international river (Islam 2013; Arora and Kipgen 2012; Somokanta 2014). Figure 1 shows the nexus of rivers in north-east Bangladesh and India. 
A number of studies on the Tipaimukh Dam have revealed that the successful implementation of the project would impact perilously on Bangladesh. In 2005, a research team comprising three members-Abu Saleh Khan, Md. Sohel Masud and Wahid Palash-pursued a study titled "Hydrological Impact Study of Tipaimukh Dam of India on Bangladesh", and their findings describe the terrible potential outcomes to be faced by Bangladesh from the construction of the Dam which they have summarized in six broad categories: hydrology, flooding pattern and river-floodplain-wetland ecosystem, morphology, water quality, Dam collapse, and other general impacts (Khan et al. 2005). Arora and Kipgen (2012) have pointed out the main objections of the people from both Bangladesh and India to the Dam project which they have also grouped under six categories, albeit differently: location in a geologically unstable region; loss of biodiversity with submergence of land; economic feasibility studies and cost-benefit analysis; administrative lapses, procedural and human rights violations; social and cultural objections; and objections by Bangladesh. They argue that the proposed Dam site is located in Zone V of Seismic Zoning Map of India, and that during 1953-92, this region had experienced twenty-one earthquakes of more than $6.5^{\circ}$ on the Richter scale (see also, Abbasi 2009). The resourceful forested hills, mostly in Tamenglong and Churachandpur districts along with the richest areas in terms of flora, fauna, and aquatic systems will be submerged. Hydrology of the region will be affected. The local indigenous people will have to bear the brunt of the project's devastating impact, but they will not share the estimated revenue to be obtained from the project. Even people will not be able to afford buying electricity at a premium. There will be catastrophic effects on infrastructures including roads and highways. The indigenous Hmar and Zelinangrong Naga people's jhum (shifting cultivation) lands, wet rice fields, and forest and riverine habitat will be submerged and destroy their way of life. Official statistics shows, 1461 families will be directly displaced, while other estimate shows, the Dam will submerge areas of about $311 \mathrm{sq} . \mathrm{km}$ covering 90 villages with 1310 families, including 27,242 hectares of forest and cultivable land and posing grave threat to biodiversity, flora and fauna of the region (Pamei 2009; Yumnam 2008; cited in Arora and Kipgen 2012: 121). Apart from northeast India, the Dam will be a death-trap for Bangladesh, as about one-third of its population will be seriously affected. Sixteen districts of the Sylhet region will be directly and adversely affected (Arora and Kipgen 2012: 118-122).

Muzaffer Ahmad, an noted environmentalist and the president of Bangladesh Poribesh Andolon (Bangladesh Environmental Movement) - a leading environmentalist organization in Bangladesh-in a press conference remarked that the Tipaimukh Dam would be "a disaster for Bangladesh's river system, livelihood and environment". "We have done rigorous study on the Tipaimukh Dam", he continues, "and found that it is going to be more disastrous than the Farakka Barrage that has already destroyed the Padma river and ecology in the country's south-western region." He added, what is "power-luxury" for India is a "life-and-death question" for Bangladesh. Energy cannot be more important than human disaster, continued Muzaffer. ${ }^{6}$ Similarly, M. R. Tarafdar (2009), a waterresources expert, in an article "Tipaimukh Dam: an alarming venture" apprehended some adverse effects of the Dam. The construction of the proposed Dam would incur

${ }^{6}$ The Daily Star, 28 May 2009, Dhaka. Available at: http://archive.thedailystar.net/newDesign/news-details. php?nid=90183 (Accessed 16 Mar 2015). 
endless sufferings to Bangladesh which include hydrological drought and environmental degradation, among others. The Dam would cause the Surma and Kushiara to run dry periodically that would eventually result in agricultural, irrigational, navigational, and potable water crises. During this time, the ground water level would markedly fall which, in turn, would affect all dugouts and shallow tube-wells. Agriculture, which is dependent on both surface as well as groundwater, would embrace catastrophic effects: rice production, the main component of Bangladesh agriculture, would drastically fall, leading to an increase in poverty (see also, Islam 2013).

According to an estimate, the Barak provides Bangladesh with 7-8 percent of its water, feeding hundreds of water bodies in the north-eastern region upon which millions of agricultural and fishing people are directly dependent. The collapse of the Dam would impound billions of cubic meters of water and cause devastating floods because of its gargantuan structure. ${ }^{7}$ The Dam site is a hazardous zone that entails the highest risk seismically. Inhabitants of Manipur too have felt that this Dam could turn out to be a source of sustained-dangers such as the potential loss of local biodiversity including flora and fauna, endangered species including pythons, gibbons, and herbal and medicinal plants, and the threatening of tribal land ownership. It would cause inundation of as many as ninety villages within a 311-square-kilometre radius (Jahangir 2009; Islam 2013: Arora and Kipgen 2012). For Bangladesh, the potential impacts are even more severe. According to a group of water experts in Bangladesh:

If the Dam is constructed, 16 districts of greater Sylhet will be affected. The immense natural disaster that will take place would be irreversible. Even though the Indian government is saying once the Dam is constructed, electricity will be generated and Bangladesh will benefit by importing the electricity. It does not make sense to make a certain part of Bangladesh a desert area, solely for the purpose of importing electricity (Dainik Destiny, 31 May 2009; also cited in Islam 2013).

The livelihoods of millions of people who are largely dependent on the fresh water of the Meghna for their subsistence and for broader food security of the region are at stake. Bangladesh is already battling water shortages due to climate change. The Tipaimukh Dam would add to the environmental cataclysm already predicted by environmentalists. According to Ainun Nishat, the country director of the International Union for Conservation of Nature (IUCN), the Dam would increase the risk of floods, and the water bodies in Sylhet would be overflowing even during the winter season. More importantly, the average sea-water level would rise. Surface irrigation would be in danger and cultivation and livelihoods in the area would be adversely affected. If India made a barrage at

\footnotetext{
${ }^{7}$ Dam failure is not an atypical event. Although the respective authority of the states concealed the news of the Dam catastrophic events, numbers of cases even have been found that report that the Dam collapse in different parts of the world for the last century has killed thousands of people, and understandably these people are essentially the inhabitants of the downstream region (Khan et al. 2005). The country specific information on Dam collapse, as much as available, is given in Patrick McCully's book Silenced Rivers: The Ecology and Politics of Large Dams. See McCully (2001). For the Tipaimukh Dam, the possibility of earthquake cannot be dismissed. According to experts, the construction of the Dam (Tipaimukh) in a geologically sensitive zone, adjacent to the Taithu Faultline, gives rise to grave concerns about earthquake (see M. S. Siddiqui, "Non-navigational use of international water courses: Why delay ratification of the UN Convention?", The Financial Express, 19 June 2014, Dhaka). Available at: http://www.thefinancialexpress-bd. com/2014/06/19/40204 (Accessed 17 Mar 2015).Dr Soibam Ibotombi of the Department of Earth Sciences, Manipur University warns the reservoir (of the Dam) may cause seismic disturbance in quake-prone Manipur. "The likelihood that during 1991-2020 the (Tipaimukh) region would experience an earthquake of magnitude 7.6 is between 40 and 60 percent” (see Syed Zain Al-Mahmood's article titled “The Dam Debate”, Dhaka Courier, 12 January 2012, Dhaka). Available at:http://www.dhakacourier.com.bd/the-dam-debate/(Accessed 17 Mar 2015).
} 
Fulertal (through which it would be able to manage water according to its needs), and procure water from the Barak River, the Surma and the Kushiara would become virtually dry (Al-Mahmood 2009; Jahangir 2009). Anticipating other long-term impacts of the Dam on Bangladesh, Tarafdar (2009) predicts:

The rosy, prosperous and healthy scenario may soon turn into history causing despondency desperation and misery to the people inhabiting the zone which is known for abundance of water, lush green field of crops and fish sanctuary. Massive environmental degradation will occur, drastically affecting weather and climate, turning a wet cooler habitat into a hot uncomfortable cauldron. The severity of micro-climate causing heat and dry conditions will gradually increase in intensity spreading over a large area over the years. It may be mentioned that rainfall that the area gets for 4-5 months and flood water that will be released from the Dam for a short period will not be enough to replenish the ground water. Climate and environmental change will force the farmers to reluctantly resort to planting lowyielding drought-resistant crops (unknown to them).

Indian academics and environmentalists have also contested the controversial Tipaimukh Dam project. In an international conference titled "International Tipaimukh Dam Conference (ITDC-2005)" held at Dhaka in December 2005, Rabindranath, a prominent Indian water-rights activist and the coordinator of the River Basin Friends of Assam, expressed his sharp reaction to the construction of the Tipaimukh Dam, and argues that the "projected power requirement of 'seven sisters' ${ }^{8}$ is $1900 \mathrm{MW}$ in 2020 while Delhi is up to generating 60,000 MW by building dams on rivers and tributaries, many of which are main sources of water for major Bangladeshi rivers. The 22-km chicken-neck dividing the seven sisters and the rest of India would not permit the transfer of such high-velocity additional power that India has decided to sell to Laos, Vietnam, Cambodia and Thailand." ${ }^{9}$ He further noted that "this power will not light our homes. If Tipaimukh (Dam) is built, the Surma and Kushiara (in Bangladesh) will be choked in a year. The Indian government is not considering preserving human livelihoods and ecology, it is instead considering the dam issue in light of cement-mafia, ironmafia and turbine manufacturers." ${ }^{10}$ Namdingpou Kamei (2006) lists the potential far-reaching environmental and social effects of the Dam on the local people:

- A land area totaling $286.20 \mathrm{sq}$. km would be submerged forever.

- The Barak waterfalls and Zeilad Lake, which are connected with the history of the Zeliangrong people, would forever be underwater; all folklore and legends would have no verifying monuments and would become made-up stories for the next generation.

- More than 40,000 people would be rendered landless.

- Eight villages situated at the Barak Valley would be completely underwater.

\footnotetext{
$\overline{8}$ Seven north-east Indian states, such as Assam, Manipur, Mizoram, Arunachal, Meghalaya, Nagaland and Tripura are popularly called 'seven sisters.'

9 The Daily Star, 01 January 2006, Dhaka. Available at: http://archive.thedailystar.net/2006/01/01/d6010101075.htm (Accessed 16 Mar 2015).

${ }^{10}$ Ibid.
} 
- More than 90 villages, mostly in the Tamenglong district, would be adversely affected.

- About 27,242 hectares of cultivable land would be lost.

- The township of Nungba, subdivision headquarters, and the village along the NH-53 would be severely affected.

- The Dam would pose health hazards, including water borne diseases, industrial pollution, and other environmental and ecological problems due to the increased water surface.

- Increased salinity of ground water would make it unsafe for drinking and increase inconvenience to the people.

- Frequent occurrences of destructive earthquakes in the area would be possible.

- The decision was made without information from proper ecological studies, which thus overlooks the future challenges and problems that people will have to deal with.

- The construction would directly affect people's livelihoods. This natural product (water, plus its agriculture-related products), which the people rely upon for every aspect of their economy, would be totally cut off, which could result in economic and financial crises.

- Consequent displacement and destruction of the people by implementing the project would pose a grave threat to people's right to live in a vibrant democratic system.

- The project, once completed, would submerge the exotic flora and fauna and rich gene pools, as Manipur is located in one of the genetic hot spots of the world where rare biodiversity resources exist.

- There would be problems of displacement, resettlement, rehabilitation, repatriation and development.

- The construction of the Dam would be a violation of democratic principles of governance, such as inclusiveness, which acknowledges and considers indigenous voices.

- The construction would show total disregard for the Zeliangrong ancient indigenous heritage, reflecting negatively on the partiality of the government.

- Not only would the Barak basin be affected, but the Dam's construction would also affect its tributaries (cited in Islam 2013:159-160).

While these figures are largely estimated, one cannot rule out the potential colossal environmental and social disasters. The Indian government has yet to reveal the full environmental-assessment report to the public. Nonetheless, independent specialists' views on the project have engendered huge reservations over the Dam's feasibility. A sense of injustice continues to grow among the people of India and Bangladesh over the Indian government's unilateral decision. The government of India instead employed various public relations strategies, apparatuses and resources to convince the local people and the government of Bangladesh of the benefits and feasibility of the project. The current ruling party of Bangladesh, Awami League (AL), has maintained warm relations 
with India historically, and remains supportive to the Indian government's decision. ${ }^{11}$ However, people from all strata of society in Bangladesh have embarked on a massive social movement and have criticized their government's role and implicit support for the Tipaimukh Dam project (Islam 2013).

\section{Environmental resistance against the Tipaimukh Dam}

The Tipaimukh has been a life-and-death question for Bangladesh, and thus people regardless of political affiliation, intellectual and ideological background, ethnic and cultural variation, and religious affiliation have come onto a common platform to render massive protests against the construction of the Dam. With a unilateral demand for an abrogation of India's decision, protests in different forms-rallies, human chains, protest meetings, seminars and symposia, strikes, and so forth-continue to carry on across the country. Protests and demonstrations have, indeed, transcended the national boundary and taken on a transnational from. The movement thus turned to a global social and environmental movement embodying the "environmentalism of the poor."

The environmental movement in Bangladesh over the construction of the Tipaimukh Dam cannot be disconnected from the turbulent past and other bilateral tensions between Bangladesh and India, such as the disputes over the water sharing of the transboundary rivers including the Ganges and Teesta as well as unabated tensions in borders between these two nations. The trajectory of the Indo-Bangladesh relations-mostly marked by bilateral tensions - has always been a key catalyst in the domestic politics of Bangladesh, and has drawn the political lines between the ruling AL and the main opposition-Bangladesh Nationalist Party (BNP) led by Begum Khaleda Zia, which has been actively supporting the anti-Tipaimukh Dam movement. Sheikh Hasina's government which came to power in late 2008 through a participatory election, and for the second consecutive term in early 2014 through a non-participatory election ${ }^{12}$ has always been accused by the critics and the opposition parties of being pro-Indian and thus adopting a "subservient" foreign policy towards India. A number of cabinet ministers constantly remark that the Dam would not harm Bangladesh and this is reflected in the government's lukewarm response to India's decision. The four-party alliance (now extended to twenty-party alliance) led by BNP expressed its sharp reaction to the government's

\footnotetext{
11 There is a general perception in Bangladesh that Sheikh Hasina's government has virtually no concern about the disastrous impacts of the Tipaimukh Dam on Bangladesh. This perception, in fact, originates from the speeches and comments of different ministers of the government, and advisors to the prime minister at different points of time on the high-profile issue of Tipaimukh. After the agreement was signed between the Government of Manipur, NHPC Ltd. and Sutlej Jal Vidyut Nigam Ltd (SJVN) in October 2011on the construction of the Dam, Dr. Mashiur Rahman and Dr. Gowher Rizvi, advisors to Prime Minister Sheikh Hasina paid a visit to New Delhi in early December 2011 to discuss their concerns. Back home, Dr. Gowher Rizvi wrote an article in the Daily Star (13 December 2011), in which he did not express concerns on the impact of the Dam on Bangladesh which drew critical comments from members of civil society as being misconceived (see Barrister Harun ur Rashid's article titled "Tipaimukh Dam: What is the current position?", Dhaka Courier, 14 March 2013, Dhaka). Available at: http://www.dhakacourier.com.bd/tipaimukh-dam-what-is-thecurrent-position/. (Accessed 17 Mar 2015). Many times, the ministers and advisors of the AL government have asserted that the Dam would not harm Bangladesh, which has prompted people to become convinced that the government has no concern about the potential disastrous effects the Dam would cause to Bangladesh; it is rather, by speaking in this manner, endorsing the Indian government's design. (see Syed Zain Al-Mahmood's article titled "The Dam Debate" Dhaka Courier, 12 January 2012, Dhaka). Available at: http://www.dhakacourier.com.bd/the-dam-debate/(Accessed 17 Mar 2015).

12 10th parliamentary elections held on 5 January 2014 were boycotted by the major opposition alliance called 20-party combine led by BNP. The election was not only one-sided; with a majority of seats elected without any contest whatsoever, more than half the country's electorate was directly denied their right to franchise (Dhaka Courier, 20 February 2014, Dhaka). Available at: http://www.dhakacourier.com.bd/settling-for-second-best/ (Accessed 18 Mar 2015). Experts' opinion suggests that out of 300 parliamentary seats 154 elected unopposed has placed the 10th parliament to suffer serious legitimacy crisis (see Shayan S. Khan's article “The 7-year itch", Dhaka Courier, 13 March 2014, Dhaka). Available at: http://www.dhakacourier.com.bd/the-7-year-itch/ (Accessed 18 Mar 2015).
} 
stance on the Tipaimukh issue, and vowed to take the issue to international forums if the government fails to stop it. The civil society groups had also been critical of the government's role on the Tipaimukh Dam in question (Rahman 2009; Islam 2013).

Under growing pressure from the opposition parties, civil society, intelligentsia, and the media, the government proceeded to send a parliamentary delegation to India to survey the proposed Dam site. The delegation comprising ten members, all of whom were also the members of the Parliamentary Standing Committee on Water Resources led by Abdur Razzak, the then Water Resources Minister of Bangladesh, visited New Delhi en route to the Tipaimukh Dam site in Manipur in early August 2009. They however failed to survey the Dam because of weather condition (Rashid 2013; Islam 2013). The delegation members were reported to have had stressed to their Indian counterparts the need for negotiations regarding the concerns and issues raised between both countries. Concurrently, Bangladesh offered to conduct a joint study with India to examine the implications of the Dam project on the region and the future flow of water in the concerned river system, which directly affects Bangladesh due to its position as a lowerriparian country.

The civil society groups including the environmentalists in Bangladesh had formed the National Tipaimukh Dam Resistance Committee (NTDRC). A long March organized by different civil society organizations which included NTDRC and Sylhet Division Unnayan Sangram Samiti (a committee that fights for development in Sylhet Division), supported by BNP and Bangladesh Jamaat-e-Islami (BJI) - the major Islamist party in Bangladesh and often branded as a "politically hardliner", marched towards the Tipaimukh Dam site on 10 August 2009, but was stopped at the international border by the Bangladesh Rifles (BDR), currently Border Guard Bangladesh (BGB).$^{13}$ BJI's active role and support for this cause could become a genuine source of concern for India (Rahman 2009). Prior to the long March, BJI attempted to organize massive protests to mobilize people's support against the Dam, but the government managed to thwart these protest movements. All the frontline leaders of the party were arrested by the government in 2010. Although the government was showing its zero-tolerance against any popular political-resistance movement surrounding the Tipaimukh Dam in Bangladesh, massive environmental resistance overseas and online continued (Islam 2013).

In August 2009, the leaders of NTDRC at a discussion held at Dhaka Reporters Unity (DRU) in the capital warned the people about the potential danger of the Tipaimukh Dam, and asked for their spontaneous and broader participation in the anti-Dam movement. They stressed that the construction of the Dam on the Barak River would desert the northeastern region of the country, and thus they called upon the people to remain alert on the issue so that the Indian government would not be able to go ahead unhindered in its construction. The meeting was held as part of an observance with the "Global Solidarity Sit-in the Tipaimukh Dam Programme", which was observed simultaneously in different district headquarters around the country and cities around the world, including Shilchar, Calcutta and Patna, India; Canberra, Australia; Tokyo, Japan; and New York, U.S. Referring to fifty large dams in the world, an engineer named Hilal, a

13 The Bangladesh Rifles (BDR) have been renamed the Border Guard Bangladesh (BGB) after the February 2009 mutiny by the BDR regular sepoys against their senior officials who were on deputation from the army officers. For more information, see http://bgb.gov.bd/index.php/bgb/history_en. 
discussant, said that a "water syndicate" is now actively constructing more Dams on big rivers to realize their selfish interests. "Such immoral activities of the syndicate have also contributed to global climate change," he continued. Shankar Roy, a renowned Indian journalist and Dinesh Mitra, an Indian engineer who also happens to be a prominent leader of the anti-Tipaimukh Dam movement, both expressed solidarity with the participants of the program (The New Nation 2009).

George Galloway, a visiting British parliamentarian, who is internationally known for his role as a human rights defender and social activist, showed his solidarity with this movement and called for an international enquiry into the potential environmental impact of India's proposed Tipaimukh Dam. The inquiry would need to examine the impact on the population of both Bangladesh and India, he added. He opined that the project is an international issue due to its implications for the climate and the environment, and thus India's decision to build the Dam unilaterally would be "a criminal offence." He reaffirmed his benevolent support by saying "I will fight to prevent the making of this Dam. Not only the Bangladeshi people, but a section of the Indian people will also be affected. Even the Indian expatriates in London protested... against the proposed Dam" (Islam 2013: 162). Galloway led a UK delegation and a huge Bangladeshi crowd on a March on 29 November 2009, from Sylhet city to the border with India where the river Barak bifurcates into the Surma and Kushiara. The March was arranged to draw global attention to the potentially devastating impact of the proposed Dam on Sylhet and the entire north-eastern region of Bangladesh (Bdnews24.com 2009).

The leaders of Islami Andolan Bangladesh (IAB), in August 2009, submitted a memorandum to UN Secretary General Ban Ki Mun via the UNDP representative to Bangladesh, seeking help to stop the construction of the Dam. The memorandum contended that the plan to construct the Tipaimukh Dam was a clear infringement of the 1996 Bangladesh-India Joint River Commission (JRC), the International Helsinki Convention, and International River Law. It also pointed out that the construction of the Dam would bring terrible ecological and environmental changes in vast areas of Bangladesh and many states of India. On 18 September 2009, IAB arranged a March on to the Indian High Commission in Dhaka to protest against the Dam. Other major political parties such as The Communist Party of Bangladesh (CPB) have also organized movements against the Tipaimukh Dam. Juba Union, the youth wing of CPB, held a two-day DhakaSylhet road-March program to demand an immediate halt to the construction of the Dam (Islam 2013). After 2009, the movement surrounding the Dam gradually became less vibrant as Bangladesh faced other political and social crises. Most leaders of this movement got arrested and some of them faced execution or forced disappearance.

The movement in India and particularly its northeast regions against the Tipaimukh Hydroelectric Project was phenomenal. In April 2009, hundreds of people representing Bengali, Manipuri, Naga, Khasi, Reang, Dimasa, and other communities from the southern part of Assam district staged demonstration in front of the District Commissioner's office at Silchar. The demonstrators condemned the government's decision and demanded the immediate abrogation of the Dam project. Pijus Kanti Das, secretary general of the Committee on Peoples and Environment (COPE), and a number of leaders from different organizations and groups joined the demonstration. The demonstrators subsequently sent a memoranda separately to the then President Pratibha Patil; Prime 
Minister Manmohan Singh; Union Minister for Forest and Environment Jairam Ramesh; Chief Ministers of Assam and Manipur Tarun Gogoi and O Ibobi Singh respectively through the District Commissioner of Cachar. In these memoranda's, they expressed their concern for the people living upstream of Barak River and the potential environmental impact of the Dam's construction (Islam 2013). Protests also took place in Manipur, Mizoram, and Barak Valley of Assam.

As indicated earlier, the Indian government initially stated that the project's object was to contain flood-water in the Cachar plains of Assam, and therefore, the people of Cachar initially favored the Dam's construction. However, they joined the movement against the proposed Dam when it became apparent that they had been misled. In August 2009, a joint meeting between various environmental organizations of Cachar and the Manipur groups opposing the building of the Dam was held. The speakers alleged that the Indian government had been misleading the downstream people with regard to the benefits of the Dam for a long time (Islam 2013). On 28 July 2009, the Hmar People's Convention (Democratic) of Manipur issued a press release which stated that the proposed Tipaimukh Multipurpose Hydroelectric Project is a war imposed on the indigenous Hmar people and various other communities located downstream and upstream. The power-greedy governments and Dam builders in India, who are driven by short-term interests in their blind pursuit of profits, are putting indigenous communities at stake. They have not sought the consent and opinions of these indigenous communities in whose land the Dam is proposed. A statement from the press release stressed that "the Rivers that nursed and fed our honored generations before shall continue to flow for all the generations to come. We cannot allow the rivers to be disturbed and are obliged to see that no outsiders, their forces and might will destroy or disturb the natural flow of the rivers of life" (quoted in Islam 2013: 165). It also appealed to the visiting Bangladeshi parliamentary delegates to steadfastly share the concern to save the rivers Tuiruong and Tuivai; to work together for the collective good; and to save the rivers from irreparable damage. Hundreds of people held a rally in an interior town of Manipur's Tamenglong district to protest the construction of the Tipaimukh Dam in early March 2010. The participants marched through Nungba town, which they said would be affected by the proposed Dam, and submitted a memorandum to the state's chief minister with the assistance of the subdivisional officer of Nungba subdivision on 9 March 2010.

Environmental resistance against the Tipaimukh Dam has swept through (Fig. 1) North America through formal protests, organizing seminars, and submitting petitions to the United Nations (Islam 2013). Along with the physical protests on a global scale, there have been a wide range of debate, discussions and protests in the virtual world, such as blogs, Facebook, newspapers, and rallies, against the Tipaimukh Dam. More than 100 Facebook groups have been created, including "Protest Tipaimukh Dam", "Stop Tipaimukh Dam”, "Protest against Tipaimukh Dam”, “Tipaimukh Dam and Fulertal Barrage-Let's Stop India”, "Save Our Bangladesh”, “Tipaimukh Dissemination”, “Tipaimukh Barrage", and so forth. To organize and to disseminate the news and information related to the Tipaimukh Dam, a good number of blog sites have been launched. Protest Tipaimukh Dam, for instance, posted 208 articles and pieces of news analysis related to the Dam in 2009. Many other online forums have been formed to resist the Dam's construction. These forums are reported to have mobilized people's support against the Dam throughout the world. Over a dozen online petitions that collected thousands of 


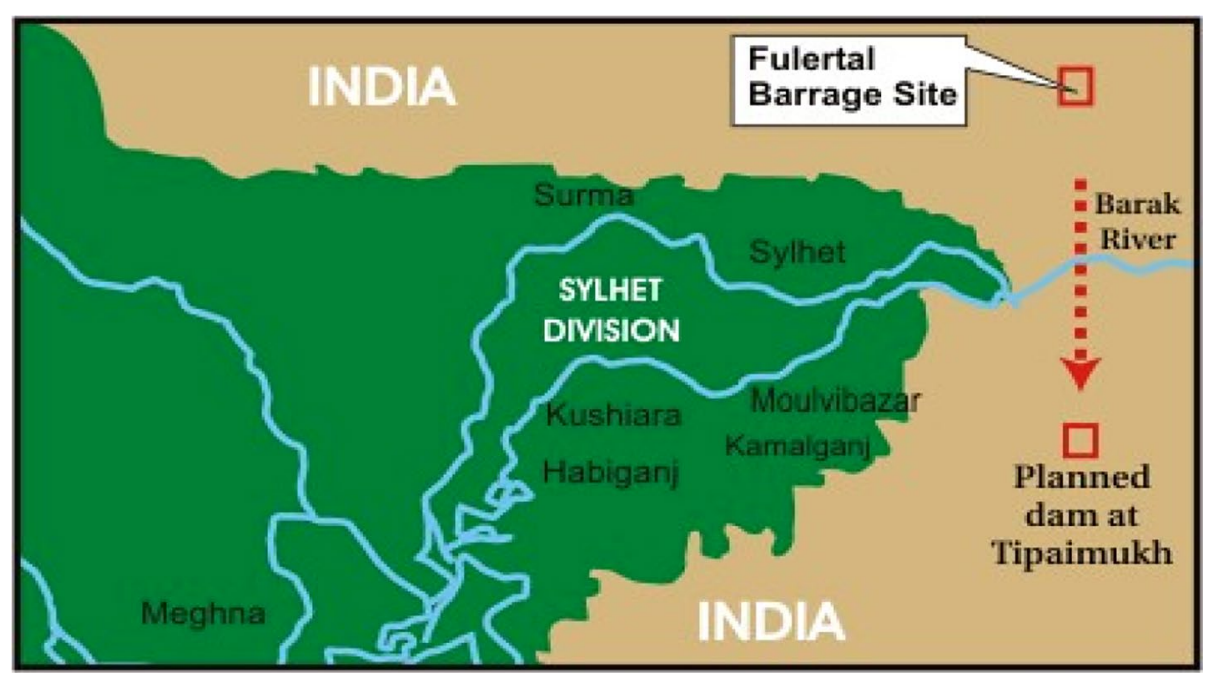

Fig. 1 The nexus of rivers in north-east Bangladesh and India. Source: Global Voices (2009)

signatures in favor of the anti-Dam movement were sent to the prime minister of India. Beyond Bangladesh, India, and North America, South Asian people inhabiting other parts of the world have expressed their deep concern about the constructions of the Dam. Adopting various means of social movement, such as protests, petitions, and other form of resistance, their endeavors have been aimed at mounting pressure on the Indian government to reconsider and to abandon the Dam project.

This "environmentalism of the poor" showed an initial success when the project was halted in 2007. The government of India, with its neoliberal agenda prioritizing economic gain over ecological and social costs, pursued this project again. Although the movement could not stop the project entirely, it pushed the government of both countries to address certain concerns. Prime Minister Sheikh Hasina brought up Bangladesh's concerns relating to the Tipaimukh Dam Project with Prime Minister Manmohan Singh during their meeting on the sidelines of the 15th Non-Aligned Movement Summit held in July 2009 in Egypt (Rahman 2009; Islam 2013). Following the signing of the "Promoter's Agreement" on the Tipaimukh Hydroelectric Project to set up a Joint Venture Company (JVC) between the Government of Manipur, NHPC Ltd. and Sutlej Jal Vidyut Nigam Ltd. in October 2011, in early December of the same year, Dr. Mashiur Rahman and Dr. Gowher Rizvi, advisors to Prime Minister Sheikh Hasina paid a visit to New Delhi to discuss Bangladesh's concerns. In September 2011, during the Indian prime minister's visit to Dhaka, a Memorandum of Understanding (MoU) titled "Indo-Bangladesh Framework Agreement on Cooperation for Development" was signed by the two Prime Ministers that prevents India from taking any unilateral decision to construct the Tipaimukh Dam. Official responses stated that technical teams from both countries should have regular meetings on this high-voltage issue (Rashid 2013). ${ }^{14}$

\footnotetext{
${ }^{14}$ The first meeting of the sub-group on Tipaimukh Hydroelectric Project under the Joint Rivers Commission was held in New Delhi on August 27-28, 2012. The second two-day meeting of the sub-group ended in Dhaka on 2nd February 2013, and Dhaka asked Delhi to provide more information and data on the water flow of the Barak River to assess the possible negative impacts of the planned dam on the common river on Bangladesh. Some experts suggest that at least 2 years would take for a comprehensive joint study on the impact of the Tipaimukh project. Thereafter the two countries will examine the report of the joint study and decide on the dam (See Rashid 2013).
} 


\section{Conclusion: towards an ecological approach}

The Dam is damn! Environmental resistance against the Tipaimukh Dam has been largely initiated by the poor; however, the magnitude and scope of the movement is undoubtedly diverse and widespread. It is still up for debate whether and to what extent this movement is successful. The resistant movement was temporarily successful when the construction work was stalled in March 2007 in the wake of protests from within and outside India. When the Indian government decided to continue with the project, environmental resistance continued to gain momentum. People in India and Bangladesh are convinced that the construction in the name of development and benefiting the local people through the provision of free electricity will eventually lead to environmental and social injustice. Tipaimukh has become a source of strain for the people of Bangladesh and India. One of their common slogans is that "Tipaimukh Dam is death to Sylhet and Bangladesh-it must be stopped." The people of both Bangladesh and India have waged a strong environmental movement against the Dam. The movement has taken various shapes-from street demonstration to indoor-protests, from seminars and discussion meetings to virtual protests through Facebook, blogs, and other online portals, from developing various environmental and social-justice organizations to making alliances among different groups to the submission of petitions to the United Nations. Originated by the poor in Asia, this environmental movement has spanned across Europe and North America.

River-interventionism has generally been the outcome of the mercantile approach to rivers, which suggests that any flow of river water to the sea is a waste, and that all of it should be used up. Such an approach contributes to the downgrading of rivers and increased conflict among countries of the river basin. In contrast, there is now a shift from a mercantile to ecological approach, which recommends preservation of the natural volume and direction of river flow. Instead of being a source of discord, as is the case with the mercantile approach; under the ecological approach, rivers represent a bond of friendship and good neighbourliness. Globally, there is also a shift from the unilateral approach toward a multilateral, basin-wide approach that includes all the countries of a river basin in decision-making processes with respect to the use of the river. Drawing insights from the environmental and social-justice movements surrounding the Tipaimukh Dam, we offer some pragmatic policy recommendations: First, India should stop proceeding any further with the Tipaimukh Dam project and engage in dialogue with Bangladesh with open-mindedness on the question of intervention on transnational rivers, particularly, which it shares with Bangladesh including the Barak River. Simultaneously, the government of Bangladesh ought to be proactive and requires diminishing its dependency on India by attaining political legitimacy through allowing and engaging in participatory democratic practices, and thus it should exert more pressure on its Indian counterpart so that the Indian government is forced to abandon its anti-people and anti-environmental Dam project. Second, India should abandon its current unilateral approach; adopt a multi-lateral, basin-wide, integrated resource-management approach to the rivers of the region; and invite Bangladesh, Nepal, Bhutan, and China to join this effort. Third, Bangladesh, India, and other countries of the subcontinent should abandon their current mercantile approach to rivers and adopt the ecological approach. Finally, all the concerned stakeholders in both Bangladesh and India, including political parties, civil society organizations, NGOs, think tanks, media, mass organizations, local people's organizations, non-resident Bangladeshis and 
Indians, and so forth, should come together, leaving behind myopic partisan and sectarian interests. Stakeholders from both Bangladesh and India should jointly form a high-profile international committee to monitor the Tipaimukh project and disseminate necessary and updated data and information. This proposed committee can coordinate and contribute to movements against Tipaimukh in India, Bangladesh and elsewhere. For Bangladesh, all concerned stakeholders including members of civil society organizations, media, NGOs, human rights organizations, intellectual groups, business and religious communities, and research organizations need to develop and rally behind a common platform and take a united national stand regarding Tipaimukh Dam and other river sharing issues, as the nation needs national unity and solidarity in order to defend its rivers.

Authors' contributions

MSI carried out the research in 2008 and 2009 on which this paper is based, and presented in a number of conferences. In 2015, MNI was invited to work on the draft to transform into a journal article. Both authors contributed equally to subsequent revisions. Both authors read and approved the final manuscript.

\section{Acknowledgements}

Earlier versions of this paper were presented at the ISA (International Sociological Association) World Congress ("Research Committee on Environment and Society, RC 24"), Gothenburg, Sweden, 11-17 July 2010 and at a special conference on "Environmental and Political Crises Looming in Bangladesh", organized by Long Live Bangladesh (LLB), Marriot Hotel in Washington D.C., May 19, 2009. The authors express their gratitude to the participants of those meetings for their insightful comments, and special thanks to Syed Serajul Islam, Tania Chowdhury and Masud Rahman.

\section{Competing interests}

The authors declare that they have no competing interests.

Received: 7 January 2016 Accepted: 7 January 2016

Published online: 30 June 2016

\section{References}

Abbasi, Arshad H. 2009. "Tipaimukh Dam, a Potential Seismic Bomb for South Asia." New Age, 2 October 2009. http:// www.sacw.net/article1161.html (Accessed 16 Oct 2015).

Adel, Miah Muhammad. 2012. Downstream ecocide from upstream water piracy. Am J Environ Sci 8(5): 528-548.

Afroz, Rounak, and Md Ataur Rahman. 2013. Transboundary River water for Ganges and Teesta Rivers in Bangladesh: an assessment. Glob Sci Technol J 1(1): 100-111.

Ahmed, Imtiaz. 2012. Teesta, Tipaimukh and River linking: danger to Bangladesh-India relations. Econ Political Wkly XLVII 16: $51-53$.

Al-Mahmood, Syed Zain. 2009. Muddying the waters. Star weekend magazine 8 (77), July 10, 2009. Available at: http:// www.thedailystar.net/magazine/2009/07/02/cover.htm (Accessed 24 Jun 2010).

Anguelovski, Isabelle, and Joan Martinez Alier. 2014. The 'Environmentalism of the Poor' revisited: territory and place in disconnected glocal struggles. Ecol Econ 102: 167-176.

Arora, Vibha, and Ngamjahao Kipgen. 2012. 'We can live without power, but we can't live without our land': indigenous hmar oppose the Tipaimukh Dam in Manipur. Sociol Bull 61(1): 109-128.

Bdnews24.com. 2009. UK MP leads march against Tipai dam. 30 November 2009. Available at: http://bdnews24.com/ environment/2009/11/30/uk-mp-leads-march-against-tipai-dam (Accessed 18 Jan 2016).

Collins, Patricia Hill. 2013. On intellectual activism. Philadelphia: Temple University Press.

Davey, lain. 2009. Environmentalism of the poor and sustainable development: an appraisal. JOAAG 4 (1): 1-10. Available at: http://joaag.com/uploads/1__4_1__Daveyfinal.pdf (Accessed 13 Mar 2015).

D'Costa, Bina. 2012. Bangladesh in 2011: weak statebuilding and diffident foreign policy. Asian Surv 52(1): 147-156.

Gari, Josep Antoni. 2000. The political ecology of biodiversity: biodiversity conservation and rural development at the indigenous and peasant grassroots. D.Phil. Thesis. UK: University of Oxford.

Global Voices. 2009. Bangladesh, India: Tipaimukh Dam and transparency, 30 July 2009. Available at: https://globalvoices. org/2009/07/30/bangladesh-india-tipaimukh-dam-and-transparency/ (Accessed 18 Jan 2016).

Guha, R., and J. Martinez-Alier. 1997. Varieties of environmentalism: essays north and south. London: Earthscan Publications.

Islam, Nahid. 1992. Indo-Bangladesh common rivers: the impact on Bangladesh. Contemporary South Asia 1(2): $203-225$.

Islam, Md Saidul. 2012. Old philosophy, new movement: the rise of the Islamic ecological paradigm in the discourse of environmentalism. Nat Cult 7(1): 72-94.

Islam, Md Saidul. 2013. Development, power, and the environment: neoliberal paradox in the age of vulnerability. New York: Routledge.

Jahangir, Nadim. 2009. Tipaimukh Dam controversy. Forum 3 (7), July 2009. Available online at: http://www.thedailystar. net/forum/2009/July/tipaimukh.htm (Accessed 25 Jul 2010). 
Kamei, Namdingpou. 2006. Controversial hydro electric (Multi-purpose) project. The Sangai Express (India). 15 December 2006.

Kazmi, Mamoona Ali. 2009. Tipaimuk Dam: a hazard for bangladesh. south asian research and analysis studies, 28 August. Available at: http://saras.org.pk/printpreview.php?topicid=1337 (Accessed 25 Jul 2010).

Khan, Abu Saleh, Md. Sohel Masud and Wahid Palash. 2005. Hydrological impact study of Tipaimukh Dam of India on Bangladesh. Dhaka: institute of water modelling (IWM). Available at: http://www.environmentportal.in/files/ Impact\%20Study\%20of\%20Tipaimukh_Final\%20Report.pdf (Accessed 15 Mar 2015).

Khan, Ashfaq Wares. 2009. Tipaimukh Dam Controversy. The Tribune, Chandigarh, 2 July 2009.

Martinez-Alier, Joan. 2014. The environmentalism of the poor. Geoforum 54: 239-241.

Martinez-Alier, Joan. 2002. The Environmentalism of the Poor: A Study of Ecological Conflicts and Valuation. Massachusetts: Edward Elgar Publishing.

Mastoor, Maryam. 2011. India-Bangladesh relations: a new phase of cooperation. Reg Stud XXIX 3: 1-34.

Mirza, M. Monirul Qader. 2009. Fallacies of India's Tipaimukh Dam. Holiday International. 4 September 2009. Available at: http://www.weeklyholiday.net/2009/040909/anniv09/21.html (Accessed 17 Jun 2010).

Nixon, Rob. 2011. Slow violence and the environmentalism of the poor. Massachusetts: Harvard University Press.

Pamei, Aram. 2009. "Say No to Tipaimukh Dam." Paper presented in a seminar titled 'Tipaimukh Mega Dam Project: Looking into the International River Laws, Environmental and Human Security Perspective' held on 28 July 2009 at BRAC INN Auditorium, Dhaka organized by the Centre for Human Rights, Development and Human Security (CHRDHS). Daily Online Alochona. http://dailyalochona.blogspot.sg/2009/08/alochona-say-no-to-tipaimukh-dam. html (Accessed 16 Oct 2015)

Peet, Richard, and Michael Watts (eds.). 1996. Liberation Ecologies: Environment, Development, Social Movements. New York: Routledge.

Rahman, Mirza Zulfikur. 2009. India, Bangladesh and Tipaimukh Dam. In IPCS (Institute of peace and conflict studies) Bulletin, No. \#2945, 17 August 2009, Available at: http://www.ipcs.org/article_details.php?articleNo=2945 (Accessed 14 Jun 2010).

Rashid, Harun Ur. 2013. “Tipaimukh Dam: what is the current position." Available online at: http://www.priyoaustralia.com. au/articles/179848-tipaimukh-dam-facts-current-position.html (Accessed 31 Mar 2015).

Riaz, Ali. 2011. Bangladesh. In Climate Change and National Security: A Country Level Analysis, edited by Daniel Moran, 103-114. Washington D.C.: Georgetown University Press.

Sinha, I.N. 1995. Opportunity, delay and policy planning vision in the synergic development of eastern himalayan rivers: a conspectus. Wat Resour Dev 11(3): 303-313.

Somokanta, T. 2014. Sociological understanding of risks: an empirical case study of Tipaimukh dam in Manipur, India. Int $J$ Innov Sustain Dev 8(4): 363-379.

Tarafdar, Mustafizur Rahman. 2009. Tipaimukh Dam: An alarming venture. The Daily Star, 25 April 2009, Dhaka. Available at: http://www.thedailystar.net/newDesign/news-details.php?nid=85451.

Tarrow, Sidney. 1994. Power in movement: social movements, collective action and politics. New York: Cambridge University Press.

The New Nation. 2009."People urged to join Tipaimukh Dam", 30 August 2009, Dhaka. http://www.ittefaq.com/ issues/2009/08/30/all0337.htm (Accessed 24 Jun 2010).

Yumnam, Jiten. 2008. "Damned hearings of proposed Tipaimukh Dam."Water for the people network. http://www. w4pn.org/index.php/latest-global-water-issues/26-india/64-damned-hearings-of-proposed-tipaimukh-dam.html (Accessed 16 Oct 2015). 